Ks. Wladyslaw Smereka, Kraków

\title{
PROCES CHRYSTUSA W ŚWIETLE NAJNOWSZYCH BADAÑ
}

Proces Chrysitusa Pana w Jerozolimie nie jest zwyczajnym wydarzeniem historycznym. $\mathrm{Ma}$ on nadzwyczajne znaczenie a to z powodu następstw jakie wynikły z tego tragicznego zdarzenia jerozolimskiego, które trwają nieprzerwanie aż po nasze czasy i trwać będą do końca życia ludzkiego na ziemi. Nie można go żadną miarą porównać z jakąś tragedią ludzką, np. z procesem Sokratesia czy innych, bo genezą swoją sięga dziejów moralnych ludzkości, to jest owego potężnego kataklizmu, jakim — wedle teologii katolickiej - był grzech pierworodny.

Proces Jezusa jest najbardziej pamietny i najbardziej znaczący ze wiszystkich wielkich procesów historii świata. Nie bez znaczenia dla oceny wagi tego procesu jest fakt, iż po powstaniu państwa Izraelskiego w $1948 \mathrm{r}$. zrodziła się koncepcja rewizji procesu Chrystusa. Wedle doniesień prasy światowej, opublikowanych 'z wiosiną 1949 r., wniosek formalny w tej sprawie, liczącej 8000 słów, w postaci 15-to stronicowego aktu, przedłożył jerozolimskiemu ministerstwu sprawiedliwości pewien prawnik holenderski, występujący pod pseudonimem H. 187.

Podobino na kilkanaście lat przedtem, podjęli rewizję procesu Chrystusa sami Żydzi; wieści o tym są jednak niepewne, a nawet częściowo sprzeczne. Wedle jednej wersji (E. S chw a rzenb a u e r: Revision des Prozesses Jesu? - Kath. Digest. 3. (1949), s. 407-409), miało to być dnia 25 czerwca 1931 r., a wedle drugiej wersji dnia 25 kwietnia 1933 r. (Jerusalem, Revue mensuelle illustrèe 28 (1933), s. 464. W jednym z powyższych dni miała się odbyć w Jerozolimie rozprawa. Przewodniczył Dr V e l d e is s e l, oskarżał w czterogodzinnej mowie Dr B a n d e is 1 e r. Po wygłoszeniu pięciogodzinnej mowy obrońcy, Dr R e i c h s w a e ra, zapadł wyrok uniewinniajacy Jezusa stosunkiem głosów cztery do jednego ${ }^{1}$.

Dla wienzącego chrześcijanina nie trzeba żadnego innego dowodu poza księgami Nowego Testamentu na to, że Jezus z Nazaretu jakko niewinny został skazany i stracony. Także niechrześcijanie, którzy dostrzegali w Nim jedną z najszlachetniejszych i najbardziej porywających postaci w historii ludzkości również byli tego zdania, gdy bez uprzedzenia i wrogiego nastawienia przystępowali do badania źródeł przewodu sądowego. Jeżeli jedniak Jezusla mimo winy skazano i wyrok wykonano, to nasuwa się

1 Por. Jos. Blinzler, Der Prozess Jezü̈ (Das jüdische und das römische Gerichtsverfahren gegen Jesus Christus auf Grund der alterem Zeugnisse dargestellt und beurteilt) Regensburg 1960, wyd. 3, s. $12 \mathrm{n}$. 
pytanie, co stanowiło podstawę prawno-formalną i materialną takiego orzeczenia i kto za nie ponosil odpowiedzialność. Odpowiedź nie łatwa.

Ewangelie nasze mimo, że nie są dziełami sensu stricto historycznymi, stanowią przecież źródło historyczne bezwzględnie prawdomówne i pewne. Jednak autorowie ich nie byli prawnikami, nie używali więc terminologii prawniczej, lecz posługiwali się zwykłym codziennym językiem, co utrudnia dziś badaczom zorientowanie się $\mathrm{w}$ zasadach procesu. Stąd różne powstały poglądy co do kompetencji Sanhendrynu w zakresie interesującego nas zagadnienia.

Według jednych do kompetencji Sanhendrynu należały sprawy gardłowe $\mathrm{z}$ tym, że zapadające wyroki śmierci wymagały zatwierdzenia władzy rzymskiej, do której należało i wykonanie wyroku. Głównym przedstawicielem tego poglądu jest wybitny badacz prawa rzymskiego Theodor M om sen ${ }^{2}$. Tezę jego przyjęli w swych rozprawach dwaj znani historycy prawa: Robert M a y ${ }^{\ddot{~}}$ i Fryderyk Doerr ${ }^{4}$. Obydwaj przedstawiając proces $\mathrm{w}$ oświetleniu prawno historycznym uwzględnili relacje Ewangelistów, prawo talmudyczne i rzymskie. Nie odbiega od tego poglądu również ks. Eug. Dąbrowski ${ }^{5}$. Inni, a w szczególności $\mathrm{G}$. $\mathrm{R}$ os a d i ${ }^{6}$ przyjmują, że do kompetencji Samhendrynu nie należały sprawy zagrożone kara śmierci, lecz tylko sprawy z zakresu religii. Proces więc Jezusa według nich przed Sanhendrynem był aktem gwałtu i przekroczeniem jego kompetencji i jako taki nie miał $\mathrm{z}$ wymiarem sprawiedliwości nic wspólnego.

Przeciwnego zdania jest paryski prawnik J. J u s t e $\mathrm{r}^{7}$. Twierdzi on, że Rzymianie pozostawili Sanhedrynowi całkowitą jurysdykcję nie tylko w zakresie spraw religijnych, lecz także w pewnych innych sprawach kryminalnych, w tym nawet $w$ gardłowych. Teze jego poparł egzegeta protestancki H. Lie tz $\mathrm{m}$ a $\mathrm{n} \mathrm{n}^{8}$. Obydwaj są jednak zdania, że w przypadku Jezusa Sanhendryn uwięził i oddał Go Rzymianom do osądzenia i wydania wyroku.

2 Römische Geschichte, Berlin ${ }^{10}$ 1927, t. IV oraz Römisches Strafrecht, Leipzig 1899, s. 240.

3 Der Prozess Jezu w Archiv für Kriminal-Anthropologie und Kriminalistik, Leipzig 1905, t. 20, s. 286 i nn.

4 Der Prozess Jezu in rechtsgeschichtlicher Beleuchtnug, BerlinStuttgart-Leipzig 1920, s. 40 i nn. Praca Doerr'a została przetłumaczona na język polski przez Stef. Glasera, prof. Uniwersytetu Wileńskiego i wydana w Wilnie w 1927 r., s. 23 nn.

5 Proces Chrystusa, Warszawa 1933.

6 Il processo di Gesú, Firenze 1933, s. 181-209.

7 Les Juifs dans l'empire romain, Paris 1914, t. 2, s. 132-145.

8 Der Prozess Jesu (Sitzungberichte der Preussischen Akademie der Wissenschaften in Berlin) Nr XIV, Berlin 1931, s. 313-322. 
Do podobnych wniosków dochodzi R. W. H u s b a n d ${ }^{9}$, uwzględniając $w$ swej pracy znalezione jurysdyczne papirusy. Wedle niego Sanhendryn aresztował Chrystusa i przeprowadził przewód sądowy jedynie $\mathrm{w}$ tym celu, aby nagromadzony materiał podać Piłatowi, od którego zależał dalszy bieg sprawy ${ }^{10}$.

Do podobnych rezultatów dochodza pisarze żydowscy jak Salomon $\mathrm{Z}$ e itl in ${ }^{11}$, Hyman $\mathrm{Cold}$ in ${ }^{12}$, Jules $\mathrm{I} z$ a a k ${ }^{13}$ i wielu. innych. Według $\mathrm{I} \mathrm{m}$ b e r t a ${ }^{14}$, prof. Instytutu katolickiego $\mathrm{W} \mathrm{Pa}-$ ryżu sąd żydowski nie wydał wyroku, lecz tylko przeprowadził przesłuchanie oskarżonego Jezusa. Paul Winte $r$ w ostatnio wydanej księżce pt On the Trial of Jesus ${ }^{15}$ obciąża głównie Piłata odpowiedzialnością za śmierć Jezusa.

Do najlepszych i najnowszych monografii o procesie Jezusa należy praca ks. Józefa Blinzle ra, profesora w Passau pt. Der Prozess Jesu ${ }^{16}$. Autor dysponując bardzo wybitną wiedzą i znakomitą pod względem formalnym metodą pogłębił po mistrziowsku objęty badaniem materiał historyiczny i nadał konkluzjom swoim niepowszednią moc przekonywującą. Ważna dla badaczy naukowych jest między innymi konkluzja oparta o ważkie i obiektywnie zebrane dokumenty, iż teza o nielegalności procesu żydowskiego, która ma wielu zwolenników pośród pisarzy nowoczesnych jest nie do utrzymania ${ }^{17}$ : historyczną odpowiedzialność za niesprawiedliwy wyrok ponoszą zdaniem Blinzle r a członkowie Sanhendrynu oraz zebrany wokół pretorium tłum jerozolimski, nie wyłączając odpowiedzialności Piłata, który przyjmując ostatecznie winę Jezusa, wyrok wykonał. Stanowisko to podziela w pewnym sensie także prof. Uniwersytetu Jerozo1916.

9 The Prosecution of Jesus. Its date, history and legatity, Princeton

10 Ks. D ą browski Eug., dz. cyt. s 46.

11 Who Crucifield Jesus? New York 1947, s. $163 \mathrm{nn}$.

12 The Case of the Nasarene Respend, New York 1948, s. 398 inn. Praca bardzo obszerna licząca ponad 800 stron. Por. również Jos Blinzle r dz. cyt. s. $142 \mathrm{nn}$, oraz recenzję tego dzieła napisaną przez J. W. w RBL V (1952), s. 488-491.

${ }_{13}$ W powieści pt. Jésus et Israel, Paris 1943 i 1948. W tym duchu napisał Schalom A s ch romans pt. Nazarener, Amsterdam 1950.

${ }_{14} \mathrm{~W}$ dziele pt. Est-ce Pilate, qui a condamne Notre Seigneur Jésus Christ? Paris 1947. Patrz J. B I inzler dz. cyt. s. 24 i nn.

15 W Studia Judaica, vol I, Berlin 1961, s. 116.

16 Wydanie drugie wyszlo w 1955 r. w Regensburgu, tamże ukazało się znacznie rozszerzone trzecie wydanie w 1960 r., o którym w tekście mowa.

${ }_{17} \mathrm{Na}$ wzmiankę zasługuje również fakt, że na paryskim Wydziale Prawa Prof. Jacquenot wraz $z$ innymi przeprowadził specjalne badanie procesu Jezusa i doszedi do wniosku, że z racji pogwałcenia przepisów prawa karnego, które miało miejsce w procesie Chrystusa wyrok był nieważny (por. Blinzle r, dz. cyt. s. 13). 
limskiego Józe $\mathrm{K} l$ a u s n e r ${ }^{18}$, który obciąża odpowiedzialnością za śmierć Jezusa arystokrację kapłańską stanowiącą trzon Sanhendrynu.

Obiektywni badacze procesu Chrystusa rozróżniają w nim cztery etapy:

1. Areszt (Mit 26, 47-56; Mr 14, 43-52; Ek 22, 47-53; J. 18, 3-12).

2. Postępowanie przed trybunałem Sanhendrynu.

3. Postępowanie przed trybunałem rzymskim (Piłatem).

4. Wyrok.

Taki schemat podają nam Ewangelie i zgadza się on $\mathrm{z}$ przepisami prawnymi Talmudu. Prawo Mojżeszowe zachowane w Starym Testamencie, daje nam zbyt ogólnikowe wiadomości o przewodzie procesowym. Wprawdzie posiadamy szczegółowy system przepisów w Talmudzie w traktacie Miszny ${ }^{19}$ pt. "Sanhendryn“, ale jest rzeczą wątpliwa, czy to prawo w Talmudzie skodyfikowane z końcem II wieku po Chrystusie, istniało i miało moc obowiązującą w czasie procesu Jezusa. Szukać zatem należy rozwiązania we wnioskach, jakie nasuwają się z porównania instytucji procesowych ówczesnych czasów, w Palestynie i w innych okupowanych prowincjach rzymskich.

W dotychczasowych badaniach poszukiwano podstawy prawnej procesu Chrystusowego w prawie talmudycznym, a nie znajdując tam rozwiązania wysuwano szereg zarzutów historycznej nieścisłości w tekstach ewangelicznych. Między innymi wedle przepisów Miszny proces karny w sprawach tzw. gardłowych mógł odbyć się tylko w dzień, a nie nocą; rozprawy sądowe w przeddzień sabbatu i świąt były zakazane; pomiędzy przesłuchaniem a wyrokiem musiała być jednodniowa przerwa; za bluźniercę uważano tylko tego, kto wymawiając imię Boże „Jahwe" równocześnie bluźnił, a wszystkie te przepisy wedle relacji Ewangelistów nie były zachowane. Aby choć częściowo usunąć te niezgodiności należy szukać innych możliwych dróg rozwiązania.

Blinzler.w swej pracy wyżej cytowanej twierdzi, że za czasów Chrystusa istniały dwa rodzaje przepisów prawnych saducejskie prawo i faryzejskie. Pierwsze było surowe, drugie bardziej humanitarne ${ }^{20}$, przy czym Chrystus miał być sądzony wedle prawa pierwszego, którego charakteru i jego poszczególnych instytucji określić nie mógł.

18 Jesus von Nazareth (Seine Zeit, Sein Leben und Seine Lehre) Berlin 1930, s. 461 i nn.

${ }_{19} \mathrm{U}$ nas proces karny w Talmudzie opracował w rozprawie pod tym tytułem Salomon L a dier (Lwów 1933 r.).

20 B linzle r, dz. cyt. s. $146 \mathrm{nn}$ i $160 \mathrm{nn}$ 
Wyniki dawnych i najnowszych badań papirologicznych pozwalają wnioskować, że Paletyna od czasów Aleksandra Wielkiego pozositawała pod silnymi wpływami świata hellenistycznego ${ }^{21}$. Ten proces $\mathrm{w}$ czasach Chrystusowych bardizo juz $\mathrm{w} \mathrm{Pa}-$ lestynie wyraźny i zalawanisowany, wycisnął pewne piętno obce nie tylko na prawie obyczajowym, lecz również na pewnych formach postępowania karnego w sądownictwie żydowskim. Przemawia za tym przypuszczeniem obok innych względów, również i fakt, że silnej hellenizacji na polu mniemań filozoficzno-religijnych i obyczajowych uległo stronnictwo Saduceuszy, do którego należał Annasz. Dodajmy, że Józef Flawiusz nazywa ${ }^{22}$ Saduceuszy szczególnie surowymi i nieubłaganymi w sądzeniu. Prawdopodobnym wydaje się, że mimo braku odnośnych postanowień w oficjalnym judejskim prawie karnym, bywało w żydowskiej praktyce sądowej niekiedy stosiowane jakieś wstępne, przed orzekajacym przewodem postępowanie inkwizycyjno-śledcze.

Znawca prawa ptolemejskiego prof. Rafał $\mathrm{T}$ a u ben$\mathrm{s} \mathrm{chl} \mathrm{a} \mathrm{g}{ }^{23}$, porównał proces świętego Pawła opisany w Dziejach Apostolskich z procesami znanymi z papirusów i wykazał wielkie podobieństwo obydwu procesów zarówno co do struktury ogólnej, jak i odrębnych sziczególów. T a u be n s chl a g rozróżnił w procesie św. Pawła postępowainie policyjne ${ }^{2 \dot{4}}$, połączone z inkwizycyjnym przesłuchaniem (zwanym w prawie ptolemejskim pethanagke, a w rzymskim quaestio per tormenta) i postępowanie sądowe ${ }^{25}$. Analogiczne dwa przewody spotykamy w procesie Chrystusowym. Pojmanie i stawienie Jezusa przed Annaszem ma znamiona postępowania policyjno-śledczego, natomiast rozprawa przed Sanhedrymem i Piłatem to dallszy tok postępowania, ale już sądrowego.

Nie znamy judejskich przepisów policyjnych co do obchodzenia się z więźniem oraz co do traktowania go przy przesłuchaniu. Sw. Jan świadczy, że Jezusa bito $w$ czasie śledztwa $(18,22)$. Egipskie prawo ptolemejskie, zachowane w papirusach, jak też i prawo rzymskie zna rozmaite tortury jako środki inkwi-

21 Por. Paul Wendland, Die Hellenistisch-Römische Kultur in ihren Beziehungen zu Judentum und Christentum, Tübingen 1907, s. 103 nn. A. J. Festugiè $\mathrm{re}$, Le monde grecoromain au temps de NotreSeigneur Jésus-Christ, 'T. I, Paris 1935 I, s. 67 nn. i R. Sug r a yer de French Etudes sur le drois palestinienien a l'epoque evangelique, Fribourg 1946, s. $132 \mathrm{nn}$.

22 Ant. 20, 9, 1.

23 Patrz jego prace: Das Strafrecht im Rechte der Papyri, Berlin 1916, s. 58 i Proces Apostola Pawta w świetle papirusów, Kraków 1920, s. 7. 24 Dz. Ap. 21, 33 i $22,24-30$.

25 Dz. Ap. 23, 25-26, 16 ,por. IM ommsen, Die Rechtsverhältnisse des Apostel Pauius w ZNW 1901, s. $89 \mathrm{nn}$; oraz cyt. wyżej prace Taubenschlaga s. $1-6$ i s. $58 \mathrm{nn}$. 
zycyjne. Reportaż sądowy św. Jana sprawia, jeśli chodzi o scenę przesłuchania wstępnego u Annasza, wrażenie skrótu; mimo to przeziera zeń specyficzna intencja Annasza, występującego tu nie w charakterze osoby prywatnej, lecz jako przedstawiciel Sanhedrynu w sensie politycznym, religijnym, społecznym i policyjnym. Intencją jego było dowiedzieć się w pierwszym rzędzie, jaką to nauke głosił Jezus, może przeciwną prawu Mojżesza i niebezpieczną dla bogactwa klas uprzywiliowanych, a następnie także, jakich to Jezus ma zwolenników (Jn 18, 12 nn.). Pierwsze z tych pytan miałoby przygotować materiał dowodowy dla trybunału żydowskiego, drugie zaś mogłoby $\mathrm{z}$ uwagi na silne podówczas napięcie ruchu wolnościowego zainteresować trybunał rzymski. Zeznania Jezusa nie wypadły po myśli pytającego dostojnika. Nie takie zeznania pragnął on usłyszeć: więc funkcjonariusz śledczy ${ }^{26}$ bije Jezusa. Przyjęlo się, że Zbawiciel otrzymał policzek; atoli słowo rapisma ${ }^{27}$ oznacza również uderzenie rózgą lub pałką.

Na możliwość przyjęcia w procesie Chrystusa fazy śledczej zwrócono uwagę w piśmiennictwie teologicznym polskim już w r. $1954{ }^{28}$. Hipotezę tę wydają się potwierdzać znalezione dokumenty z Quumran dotyczące istnienia podwójnego kalendarza ${ }^{29}$. Opierając się na tradycyjnym kalendarzu kapłańskim należałoby przyjąć iż pojmanie Chrystusa nastąpiło w nocy $z$ witorku na środę a nie z czwartku na piątek. W takim przypadku było dość czasu, by przeprowadzić śledztwo przed Annaszeem i odbyć w d z i e ń (środa i czwartek) dwie rozprawy przed Sanhedrynem. Koncepcja taka stanowi niewątpliwie przyczynek w usiłowaniach wytłumaczenia dopatrywanych się nieścisłości w opisie Męki Chrystusa przez Ewangelistów.

Gdyby jednak jakieś znaleziska archeologiczne nadal rozszerzały materiał istotny do oceny procesu Chrystusowego, zawsze należy mieć na uwadze, że przed Annaszem, Kajfaszem, Herodem i Piłatem oraz żądnym śmierci tłumem jerozolimskim stał

26 Sw. Jan nazywa go hyperetes; wyraz ten nie oznacza prywatnego służącego. W znaczeniu urzędowej osoby używa tego słowa św. Mateusz $(5,25)$.

27 W. B a ue r, Wörterbuch zum N. Test., Giessen 1928, c. 1178 n; Fr. Z or e11, Lexicon Graecum N. Testamenti, Parisiis 1931, c. 1175.

$28 \mathrm{Ks}$. Smejeka, Annasz $i$ jego udziat $w$ procesie Chrystusa w RBL VII (1954) s. $139-155$.

${ }_{29} \mathrm{Za}$ czasów Chrystusa był w użyciu podwójny system liczenia czasu - oficjalny księżycowy hellenistyczny i stary tradycyjny zachowany przez pewne środowiska religijne. Por. A. J a ubert, La Date de la Cène (Calendier Biblique et Liturgie Chretienne), Paris 1937, s. 136 nn. i 139 nn., oraz G. Danesi, Le Settimona Saita u Moraldi, Introduzione della Biblia (Roma) 537-540). Ks. J. E a ch, Ostatnia wieczerza we współczesnej problematyce biblijnej 12 (1959), s. $138 \mathrm{nn}$. 
nie człowiek zwyczajny, całkowicie równy innym ludziom, lecz Bóg-Człowiek. Dlatego zbłądziłby zasadniczo ten, kto chciałby wyodrębnić wstrząsającą tragedię jerozolimską z dziejów całej ludzkości i rozplatrywać proces Chrystusowy z punktu li tylko prawniczego lub historycznego nie uwzględniając również jego teologicznego aspektu.

Kraków

KS. WEADYSEAW SMEREKA

\section{O. Augustyn Jankowski OSB, Tyniec}

\section{ELEMENTY TEOLOGII MĘCZENSSTWA W LIŚCIE DO FILIPIAN}

Męczeństwo, rozumiane precyzyjnie po katolicku, zjawisko towarzyszące od początku dziejom Objawienia i dziejom Kościoła, słusznie stamowi przedmiot zainteresowania również i teologów. Jego zaś teologię można ujmować na różne sposoby. I tak św. Tomasz z Akwinu, opracowując teologicznie zagadnienie męczeństwa, umieszcza je $\mathrm{w}$ ramach rozważań o cnocie męstwa ${ }^{1}$. Jak $\mathrm{z}$ tego widać, stosuje on jako ramę $\mathrm{z}$ góry przyjęty arystotelesowski schemat cnót kardynalnych. Innymi słowy etyka, i to ujęta w zasadzie od strony człowieka, dyktuje mu całe ujęcie zagadnienia i dostarcza gotowych ram. Natomiast cytaty z Pisma św. i głosy Tradycji stanowią dla niego argumenty mające uzasadnić poszczególne twierdzenia. Przy tym ujęciu materiał na ten temat zawarty w Liście św. Pawła do Filipian prawie zupełnie nie został uwzględniony. Jedno bowiem jedyne miejsce $\mathrm{z}$ niego przytoczone, mianowicie przykład samego Chrystusa z 2, 8, służy za dowód wyższości męczeństwa nad cnotą posłuszeństwa ${ }^{2}$. Sposób ujęcia zagadnienia za św. Tomasziem powtarzają podręczniki i encyklopedie, poszerzając co najwyżej o opracowanie kanonistyczne i ocenę wartości apologetycznej męczeństwa $^{3}$, co jednak nie stanowi jego teologii $w$ sensie ścisłym. Wobec tego nie wydaje się przedsięwzięciem chybionym próba skonstruowania teologii męczeństwa wedłlig zasad dzisiejszej teologii biblijnej, tzn. obrania za punkt wyjścia przede wszystkim danych zawartych $\mathrm{w}$ tekście natchnionym, a następnie dokonania syntezy tych danych. Biblijna teologia męczeństwa musiałaby uwzględnić już ostatnie księgi Starego Testamentu, potem przejść do Nowego - zadanie to wielkie. Niniejszy artykuł ma

1 Par. S. Theol. II-IIae q. 124.

2 Tamże, a. 3 ad $2-m$.

3 Por. R. H e d de, Martyre, Dictionnaire de Théologie Catholique, X, $220-254$. 